Article

\title{
Fabrication and Microstructure of Laminated HAP-45S5 Bioglass Ceramics by Spark Plasma Sintering
}

\author{
Ye Meng ${ }^{1,2, *}$, Wenjiang Qiang ${ }^{1}$ and Jingqin Pang ${ }^{1,2}$ \\ 1 School of Materials Science and Engineering, University of Science and Technology Beijing, Beijing 100083, \\ China; wjqiang@mater.ustb.edu.cn (W.Q.); jqpang2010@163.com (J.P.) \\ 2 National Demonstration Center for Experimental Materials Education, University of Science and Technology \\ Beijing, Beijing 100083, China \\ * Correspondence: mengye@ustb.edu.cn; Tel.: +86-187-0169-7066
}

Received: 6 January 2019; Accepted: 3 February 2019; Published: 4 February 2019

\begin{abstract}
Hydroxyapatite (HAP) has excellent biocompatibility with living bone tissue and does not cause defensive body reactions, therefore, it has become one of the most widely used calcium phosphate materials in dental and medical fields. However, its poor mechanical properties have been a substantial challenge in the application of HAP for the replacement of load-bearing or large bone defects. Laminated HAP-45S5 bioglass ceramics composites were prepared by the spark plasma sintering (SPS) technique. The interface structures between the HAP and 4555 bioglass layers and the mechanical properties of the laminated composites were investigated. It was demonstrated that there was mutual transfer and exchange of $\mathrm{Ca}$ and $\mathrm{Na}$ atoms at the interface between $45 \mathrm{~S} 5$ bioglass/HAP laminated layers, which contributed considerably to the interfacial bonding. Due from the laminated structure and strong interface bonding, laminated HAP-45S5 bioglass is recommended for structural applications.
\end{abstract}

Keywords: hydroxyapatite; $45 \mathrm{~S} 5$ bioglass; laminated; spark plasma sintering; interfaces structures

\section{Introduction}

In recent years, laminated ceramics have attracted considerable attention due to their high fracture toughness, fracture work, and flexural strength [1-5]. In the 1990s, based on the bionic structures, such as bamboo and shells, Clegg designed and prepared $\mathrm{SiC} /$ graphite laminated composite ceramics, which improved the fracture toughness of laminated composite ceramics from $3.6 \mathrm{MPa} \cdot \mathrm{m}^{1 / 2}$ to $15 \mathrm{MPa} \cdot \mathrm{m}^{1 / 2}$ and the fracture work from $28 \mathrm{~J} \cdot \mathrm{m}^{-2}$ to $4625 \mathrm{~J} \cdot \mathrm{m}^{-2}$ [6]. Since then, the research on laminated composites has been unprecedentedly active. Xie et al. [7] prepared laminated $\mathrm{SiC}_{\mathrm{w}} / \mathrm{SiC}$ ceramic composites by the combination of chemical vapor infiltration and tape casting. The volume fraction of whiskers reached as high as $40 \mathrm{vol} . \%$, and the flexural strength, tensile strength, and fracture toughness were $315 \mathrm{MPa}, 158 \mathrm{MPa}$, and $8.02 \mathrm{MPa} \cdot \mathrm{m}^{1 / 2}$, respectively. Since then, more laminated ceramic materials have been developed, including laminated $\mathrm{SiC}$ ceramics [8-10] and laminated $\mathrm{Si}_{3} \mathrm{~N}_{4}$ ceramics [11,12].

Hydroxyapatite (HAP) possesses good bioactivity and compatibility with roughly the same component and crystal structure as the human skeleton [13]. However, the application of HAP has been largely limited by its low fracture toughness $\left(0.8-1.2 \mathrm{MPa} \cdot \mathrm{m}^{1 / 2}\right)$ and flexure strength (140 MPa) [14]. To improve the mechanical properties of HAP, reinforcements such as zirconia, alumina, carbon fiber, and carbon nanotubes are incorporated to make HAP-based composites [15-18].

$45 \mathrm{~S} 5$ bioglass is a biocompatible material with remarkable osteoconductivity, osteoinductivity, and controllable biodegradability [19-22]. Hench et al. developed $45 \mathrm{~S} 5$ bioglass, composed of $45 \mathrm{wt} . \% \mathrm{SiO}_{2}$, 
24.5 wt. $\% \mathrm{Na}_{2} \mathrm{O}, 24.5 \mathrm{wt} . \% \mathrm{CaO}$, and 6 wt. $\% \mathrm{P}_{2} \mathrm{O}_{5}$ [23]. The $45 \mathrm{~S} 5$ bioglass can be further strengthened by the incorporation of metal, polymer, and fiber [24-26].

Recently, many attempts to combine HAP with bioactive glasses have been reported, such as sol-gel [27-30], hot-press sintering [31,32], pressureless sintering [33,34], and SPS [35-37]. HAP composite produced with sol-gel has been mainly used as a porous coating on metallic implants in orthopedic and dental applications to combine the excellent mechanical properties of metals and bioactivity of hydroxyapatite [28]. The higher temperature $\left(1200-1350^{\circ} \mathrm{C}\right)$ required for the conventional sintering (hot-press sintering, pressureless sintering) of this composite system results in the complete crystallization of bioglass and excessive reactions between bioglass and HAP, which are suspected to delay the bioactivity response [35]. SPS is a pressure-assisted synthesis and processing technique which employs high current (pulsed direct current) and low voltage. In the SPS technique, there is direct heating of the sample in a graphite mold. A pulsed direct current (DC) passes through graphite punch rods and dies simultaneously with uniaxial pressure [38]. The SPS method allows fine tuning of the sintering process (pressure, temperature, time, and higher heating rates) which is crucial for HAP-bioglass sintering. In comparison with conventional sintering techniques, higher heating rates (between 100 and $600{ }^{\circ} \mathrm{C} / \mathrm{min}$ ) can be achieved. With such high heating rates, densification mechanisms are favored [39]. Grasso et al. [40]. reported the sintering of bioglass powder by SPS with temperature $\left(350-500{ }^{\circ} \mathrm{C}\right)$ and pressure $(70-300 \mathrm{MPa})$, respectively. They found that the density of the samples is strongly affected by the applied pressure. When the sintering temperature was below $\mathrm{Tg}$, high pressure promoted the compaction of powders. In order to achieve samples with density higher than $95 \%$, a sintering pressure of $300 \mathrm{MPa}$ was needed at $500{ }^{\circ} \mathrm{C}$. By increasing the sintering temperature up to $550^{\circ} \mathrm{C}, 70 \mathrm{MPa}$ of pressure was enough to achieve samples with a density exceeding 98\% [40]. Gergely et al. [41]. confirmed that due to the rapid sintering time (5 $\mathrm{min}$ ) applied during the SPS process, the phase composition was not changed with the temperatures $\left(800-950{ }^{\circ} \mathrm{C}\right)$ used. Dubey et al. [42]. observed that HAP began to dissociate to $\beta$-tricalcium phosphate ( $\beta$-TCP) when SPS was sintered at $1200^{\circ} \mathrm{C}$. As has been reported, composites of HAP and TCP induce moderate initial inflammatory responses compared with HAP alone [43]. $\beta$-TCP, HAP, and processed spongiosa are common materials for filling bone defects. Bone grafts become incorporated by the host bone and are substituted either completely ( $\beta-\mathrm{TCP}$, processed spongiosa) or partially (HAP) [44]. Therefore, we hope to sinter HAP-bioglass laminated composites without decomposition of HAP into $\beta$-TCP. SPS requires relatively low temperatures to reach high consolidation levels. Consequently, SPS is beneficial in the sintering processes where crystallization phenomena, grain growth, and/or phases decomposition have to be avoided or minimized [36]. There are two main motivations for sintering calcium phosphates with a glassy phase: on one hand, it is possible to tune the dissolution of the final system to enhance its biological response through the synergistic combination of two bioactive phases; on the other hand, the glass acts as a sintering aid with the aim to increase the densification of the composite and thus its mechanical strength [45]. 45S5 bioglass-coated implants exhibited greater bone ingrowth compared to hydroxyapatite (HA)-coated and as controls (CTL) implants, and they maintained their mechanical integrity. The bioactive glasses are commonly more reactive than HA, and hence the combination of HA and bioactive glasses is promising and may lead to the development of new-generation composites with tailored biological properties [46]. Several studies [47-50] have described metalo-ceramic composites obtained by fine tuning of SPS sintering properties. These studies all use intermetallic compounds as reinforcing phases to improve the overall hardness, strength, or wear resistance of the composite structure, while tough metal phases provide appropriate ductility, fracture toughness, and machinability. The inherent SPS technology features, such as rapid heating rates, short sintering times, and applied external pressure (which improves the densification) [51], enable excellent sintering while avoiding formation of microstructural issues related to, e.g., excessive grain growth, development of porosity, or microstructural heterogeneities.

In this study, laminated structures were introduced into structural materials. Laminated HAP-45S5 bioglass ceramics composites were prepared by SPS. In addition, monolithic HAP ceramics 
were fabricated under the same conditions for comparison. The microstructure evolution and mechanical properties were thoroughly investigated.

\section{Materials and Methods}

HAP powder (molecular formula is $\mathrm{Ca}_{5} \mathrm{HO}_{13} \mathrm{P}_{3}$ ) with purity of $97 \%$ and $\mathrm{d}_{90}<200 \mathrm{~nm}$ was provided by Sigma-Aldrich. Co., St. Louis, MO, USA. The $45 \mathrm{~S} 5$ bioglass powder was provided by MO-SCI Corporation in the Rolla, MO, USA, with a chemical composition (wt.\%) of $45 \% \mathrm{SiO}_{2}$, $24.5 \% \mathrm{Na}_{2} \mathrm{O}, 24.5 \% \mathrm{CaO}$, and $6 \% \mathrm{P}_{2} \mathrm{O}_{5}$ and $\mathrm{d}_{90}<6 \mu \mathrm{m}$. The mass ratio of HAP:45S5 bioglass was 2:1. Ten $\mathrm{g}$ HAP or $45 \mathrm{~S} 5$ bioglass were mixed in $60 \mathrm{~mL}$ alcohol by magnetic stirring for $2 \mathrm{~h}$ at the speed of $300 \mathrm{rpm}$, and then dried in an oven at $343 \mathrm{~K}$ for $15 \mathrm{~h}$.

The powders of the corresponding quality are put into the graphite die (Beijing Sanye Carbon Co., Ltd., Beijing, China) layer by layer in a certain order (Figure 1a). The masses of the HAP layer and the $45 \mathrm{~S} 5$ bioglass layer were $1 \mathrm{~g}$ and $0.5 \mathrm{~g}$, respectively. The inner diameter of the graphite mould is $20 \mathrm{~mm}$. And a sheet of graphite paper was placed on the inner wall of the mould to facilitate the demoulding. Each layer was loaded axially with a pressure of $20 \mathrm{MPa}$ to fabricate the preform. The preform was consolidated by SPS equipment (SPS. Dr Sinter 1050, Sumitomo Coal Mining Co., Ltd., Tokyo, Japan) at $1223 \mathrm{~K}, 40 \mathrm{MPa}$ (process planning according to Ref. [40,52,53]). The heating rate was increased from room temperature to $1123 \mathrm{~K}$ at $100 \mathrm{~K} / \mathrm{min}$, then decreased to $50 \mathrm{~K} / \mathrm{min}$ to $1173 \mathrm{~K}, 30 \mathrm{~K} / \mathrm{min}$ to $1203 \mathrm{~K}$, $20 \mathrm{~K} / \mathrm{min}$ to $1223 \mathrm{~K}$, and kept for $5 \mathrm{~min}$ at $1223 \mathrm{~K}$. The intent keeps the temperature stable during the holding process on the basis of rapid sintering. At the initial stage of sintering, $10 \mathrm{MPa}$ pressure was applied on the head, and $10 \mathrm{MPa}$ pressure was increased at $873 \mathrm{~K}, 973 \mathrm{~K}$, and $1073 \mathrm{~K}$, respectively, then $40 \mathrm{MPa}$ pressure was maintained at thermal insulation (Figure 1b). Afterwards, the pressure was reduced slowly to $0 \mathrm{MPa}$ before the temperature drops to $873 \mathrm{~K}$ to release the internal stress sufficiently during the cooling process and to avoid the cracking of the sample.
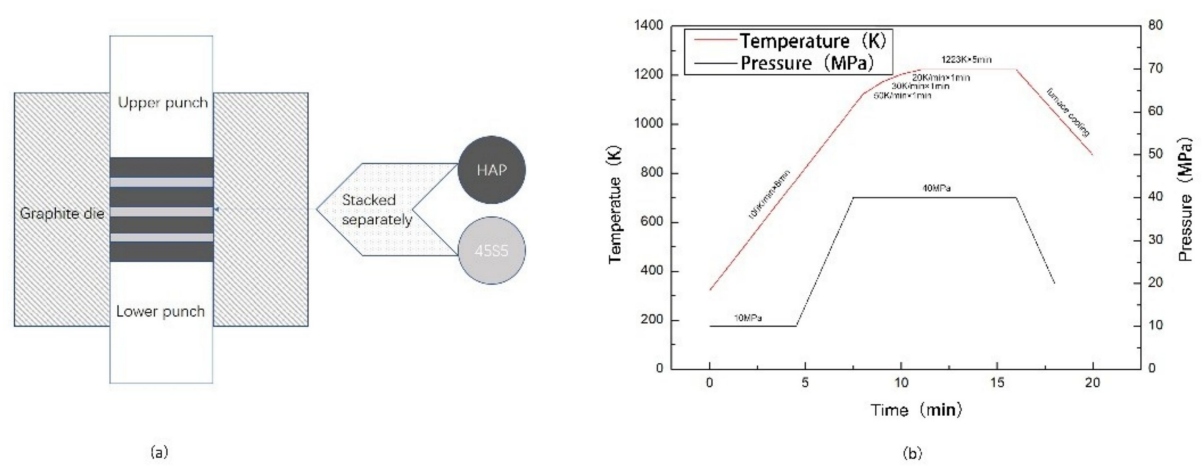

Figure 1. Preparation of laminated HAP/45S5 bioglass ceramic: (a) The green body structure of HAP-45S5 bioglass laminated composite material; (b) The sintering process by spark plasma sintering.

Finally, the samples were cut into bars with dimensions $2.5 \mathrm{~mm} \times 2.5 \mathrm{~mm} \times 18 \mathrm{~mm}$ to examine the mechanical properties and microstructure. The microstructures and fractured surfaces were characterized by field emission scanning electron microscopy (FESEM, Zeiss Supra55, Oberkochen, Germany). The 3-point bending test is measured by the Microcomputer Control Universal Test Machine (WDW-1, MTS Systems Corporation, Eden Prairie, MN USA) with a loading rate of $0.5 \mathrm{~mm} / \mathrm{min}$.

\section{Results and Discussions}

Figure 2 shows the SEM images of the raw materials of HAP and $45 \mathrm{~S} 5$ bioglass. It is shown in Figure 2a that the raw HAP powder is spherical with a relatively uniform particle size and the average size as $200 \mathrm{~nm}$. In contrast, as shown in Figure 2b, the 45S5 bioglass powder particles are highly irregular. The large particles $(\sim 5 \mu \mathrm{m})$ with sharp edges are attached massive small particles $(1 \mu \mathrm{m})$. 
Figure 3 shows the SEM image of the fresh fracture surface of the laminated HAP-45S5 bioglass ceramic composite. As clear, the HAP-45S5 bioglass composite, in which the $800 \mu \mathrm{m}$ thick $45 \mathrm{~S} 5$ bioglass is favorably sandwiched by grey HAP layers, shows a well-laminated structure with clear and parallel interfaces. Noteworthy that such composite is sintered by SPS at a low temperature $(1223 \mathrm{~K})$ and short time $(16 \mathrm{~min})$, which are superior to traditional sintering techniques such as hot pressing which generally requires a higher temperature of $1273-1573 \mathrm{~K}$ and longer sintering time of 60-120 min [54-58]. The rapid sintering can effectively suppress the grain growth and excessive interfacial reaction, which are favorable for the mechanical properties of the composites.

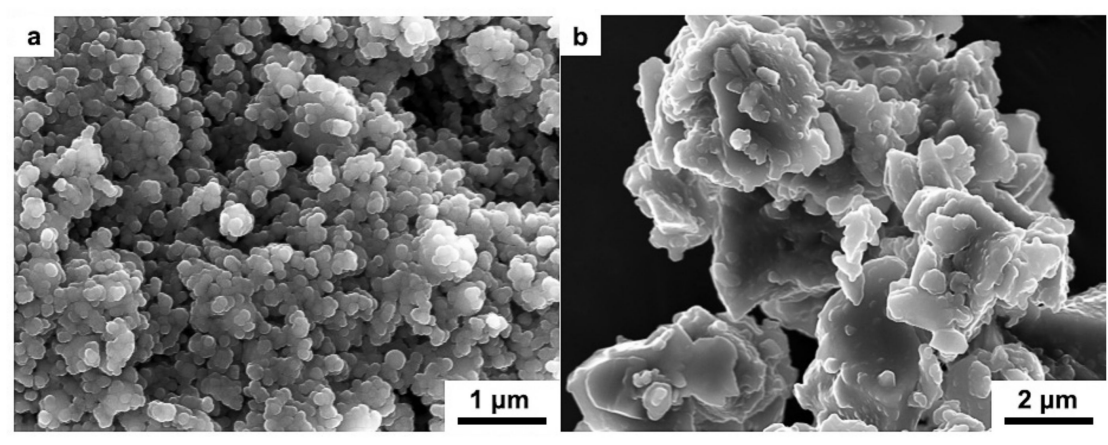

Figure 2. SEM images of raw materials: (a) pure HAP powder and (b) pure $45 \mathrm{~S} 5$ bioglass powder.

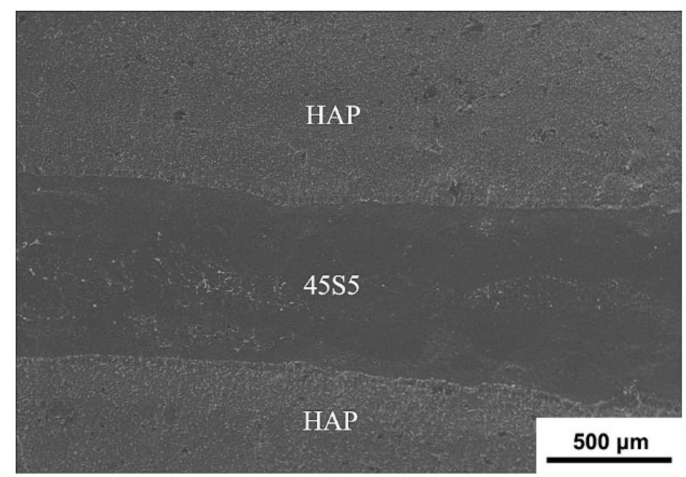

Figure 3. SEM micrograph of the fracture surface of laminated HAP-45S5 bioglass ceramics.

Figure 4 shows the SEM images of the fracture surface of laminated HAP-45S5 bioglass ceramics composite. As seen, the 45S5 bioglass layer presents a porous microstructure (Figure 4b) with isolated, irregularly shaped pores surrounded by dense walls. The HAP layer displays a stratified distribution of two kinds of grains. The HAP particles near the side of $45 S 5$ bioglass layer are larger (Figure 6c) with an average particle size of $2 \mu \mathrm{m}$, while the HAP particles far from the 45S5 bioglass layer are smaller (Figure $6 \mathrm{~d}$ ) with an average particle size of $1 \mu \mathrm{m}$. Figure $4 \mathrm{~b}-\mathrm{d}$ shows the characteristics of the three layers. In the 45S5 bioglass layer, holes of different sizes are distributed in the layer. From the hole, it can be seen that the 45S5 bioglass maintains its original shape and the particle size is basically kept within 1-2 $\mu \mathrm{m}$. This porosity could be formed by the development of the gaseous byproducts during the sintering (Figure 4b) [21]. The grains of the HAP close to the $45 \mathrm{~S} 5$ bioglass layer grow obviously, up to $2 \mu \mathrm{m}$. It can be seen the melting phenomenon of $45 \mathrm{~S} 5$ bioglass in contact with HAP. On the contrary, the 45S5 bioglass far from HAP retains its original shape and pore structure. This indicates that the sintering temperature at the contact point of $45 \mathrm{~S} 5$ bioglass with HAP is higher than those in the phase of $45 \mathrm{~S} 5$ bioglass or HAP. The relatively high temperature melts $45 \mathrm{~S} 5$ bioglass and causes the grain growth of HAP (Figure 4c). Hence, the addition of glass can significantly enhance the sinterability of HAP [59]. As a result, the HAP grains far from $45 S 5$ bioglass retain their fine and compact structure with a particle size of $1 \mu \mathrm{m}$ (Figure $4 \mathrm{~d}$ ). Meanwhile, it can be seen that the samples possessed a rather compact structure with good interfacial bonding. Compared with porous materials, the bacterial 
counts of Staphylococcus growing on the surface of smooth materials is lower [44]. Staphylococci are considered the most infecting microorganisms of bone tissue, with Staphylococcus aureus being the most commonly found species. The composites have advantages in avoiding infection and complications when it is used as an intraosseous implant to repair alveolar ridge after tooth loss [60].

To reveal the diffusion phenomena at the interface, the interface of the laminated HAP-45S5 bioglass ceramics was analyzed by Energy dispersive X-ray spectroscopy (EDX), as shown in Figure 5. From the $45 \mathrm{~S} 5$ bioglass layer to the HAP layers, the amount of Si gradually decreases. At the same time, the amount of $\mathrm{P}$ gradually reduces from the HAP layer to the $45 \mathrm{~S} 5$ bioglass layer. In addition, in the portion of coarse grain HAP adjacent to $45 \mathrm{~S} 5$ bioglass, Ca content is decreased while Na content is increased. The structure of HAP can easily accommodate a great variety of anionic and cationic substitutes [61]. In this layer, Ca ions are replaced by Na ions [62], and thus the opposite diffusion path of $\mathrm{Ca}$ and $\mathrm{Na}$ occurs. The diffusion of $\mathrm{Na}$ out from the glassy phase and its replacement from the diffusion of $\mathrm{Ca}$ from the CaP based phase makes the BG less vulnerable towards crystallization [63].

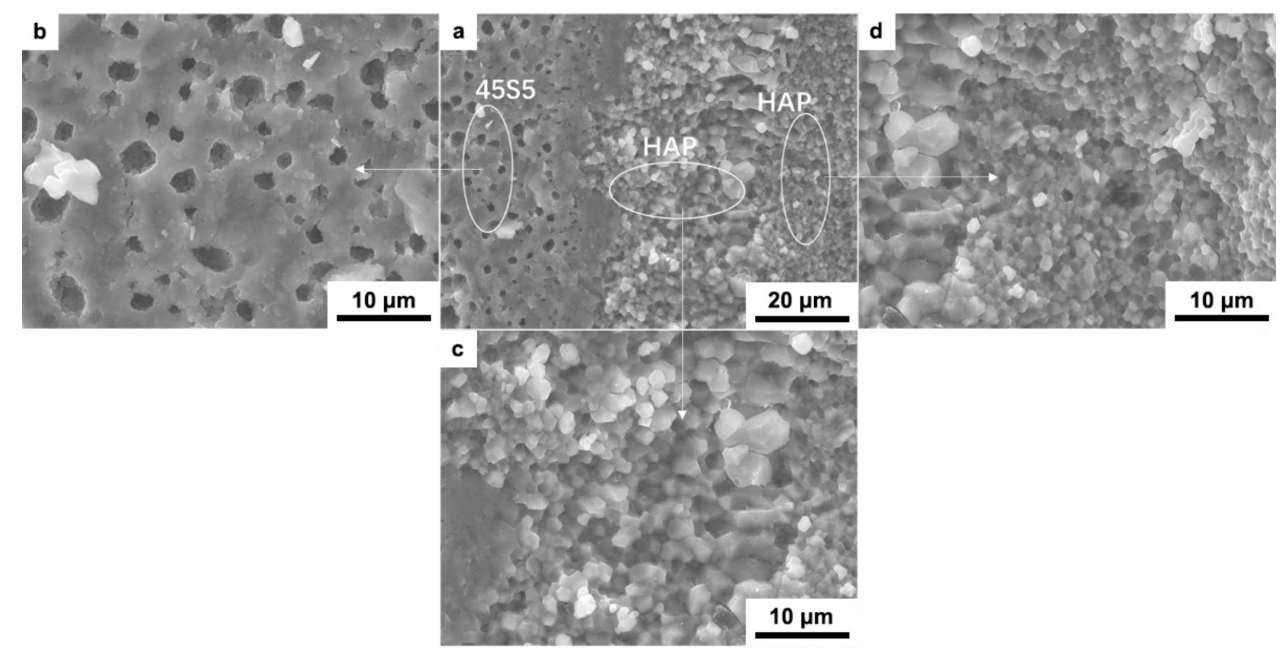

Figure 4. SEM images of the fracture surface of laminated HAP-45S5 bioglass ceramics (a); enlarged figure of $45 \mathrm{~S} 5$ bioglass layer (b) and HAP layers (c,d).

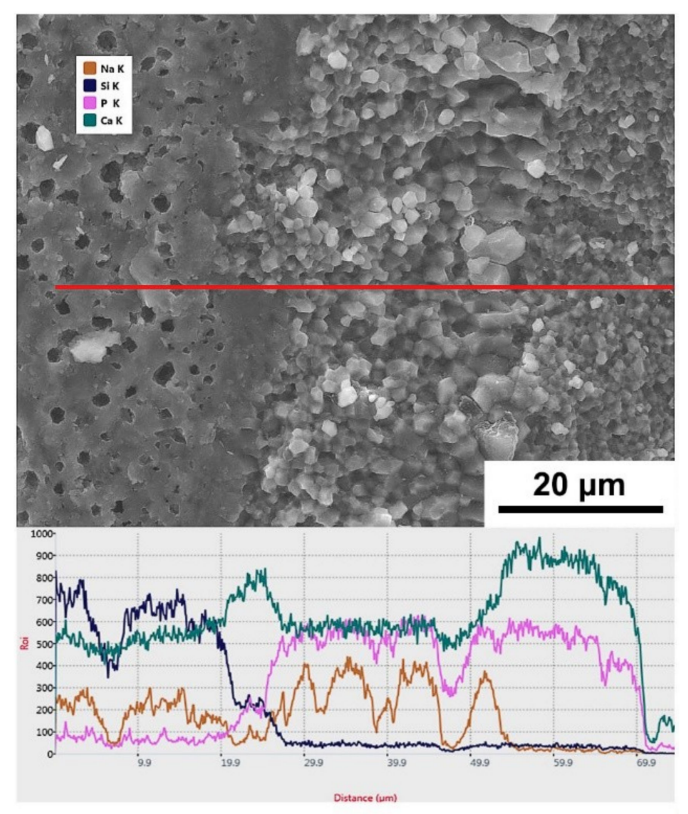

Figure 5. SEM micrograph of laminated ceramics fracture surface and element diffusion analysis of EDX. 
To clearly observe the migration and change of the main elements of the HAP / $45 \mathrm{~S} 5$ composites before and after sintering, the atomic percentages of the elements $(\mathrm{Si}, \mathrm{Na}, \mathrm{Ca}$, and $\mathrm{P}$ ) in $45 \mathrm{~S} 5$ bioglass and HAP are based on the EDX spot results, which are listed in Table 1.

Table 1. Atomic weight percentage of $\mathrm{Si}, \mathrm{Na}, \mathrm{Ca}$, and $\mathrm{P}$ in raw powder of $45 \mathrm{~S} 5$ bioglass and $\mathrm{HAP}$ and those in laminated HAP-45S5 bioglass ceramics.

\begin{tabular}{cccccc}
\hline \multirow{2}{*}{ Sample } & \multicolumn{3}{c}{ Atomic Weight Percentage/\% } \\
\cline { 3 - 5 } & & Si & Na & Ca & P \\
\hline \multirow{2}{*}{ Raw powder } & 45S5 bioglass & 35.31 & 30.93 & 29.59 & 4.17 \\
& HAP & 0 & 0 & 68.26 & 31.74 \\
\hline \multirow{3}{*}{ Sintered specimen } & 45S5 bioglass layer & 36.52 & 11.69 & 71.69 & 6.21 \\
& coarse grain HAP layer & 0.97 & 52.44 & 24.00 & 22.60 \\
& fine grain HAP layer & 0 & 7.21 & 60.5 & 32.29 \\
\hline
\end{tabular}

As seen, the contents of $\mathrm{Si}$ and $\mathrm{P}$ in the $45 \mathrm{~S} 5$ bioglass layer do not change significantly. At the same time, the $\mathrm{Na}$ concentration decreases by nearly a factor of $2 / 3$, while the Ca concentration is increased by more than a factor of 2 . It can be seen that the $\mathrm{Na}$ and $\mathrm{Ca}$ atoms in the $45 \mathrm{~S} 5$ bioglass layer are transferred in the opposite directions in the composites, as shown in Figure 6a. A very small amount of $\mathrm{Si}$ appears in the HAP coarse grain layer adjacent to the $45 \mathrm{~S} 5$ bioglass layer, which transfers from $45 \mathrm{~S} 5$ bioglass to HAP during sintering. Meanwhile, in the HAP coarse grain layer, the P content decreases slightly, while the Ca content decreases by nearly $60 \%$, and the Na content reaches $52.44 \%$. It can be seen that in the HAP coarse grain layer, $\mathrm{Na}$ and $\mathrm{Ca}$ atoms also transfer in the opposite direction, and this phenomenon is contrary to that in the $45 \mathrm{~S} 5$ bioglass layer. Therefore, it can be concluded that the $\mathrm{Ca}$ and $\mathrm{Na}$ atoms exchange between $45 \mathrm{~S} 5$ bioglass layer and HAP coarse grain layer. Meanwhile, it can be seen that a very small amount of $\mathrm{P}$ atoms was transferred from the HAP layer to the 45S5 bioglass layer, as shown in Figure 6b. The trend of decrease in Ca content and increase in Na content in the HAP fine grain layer tends to decrease, and the percentage of $\mathrm{P}$ atomic mass remains almost unchanged. No evidence of $\mathrm{Si}$ atoms can be found. It can be seen that the far distance from the 45S5 bioglass layer to HAP lead to a long time for atom transfer due to the increase of diffusion activation energy, as shown in Figure 6c. The P atoms and Si atoms are maintained in their original positions and do not diffuse, as elements undergoing diffusion can bond closely with each other. Also, the presence of $C$ atoms is detected in all three layers after sintering. It is well-accepted that carbonates are easily generated in Ca-containing minerals. Besides, the mechanism of carbonation depends on the type of formed carbonates and the type of substrates [64]. The existence of large amounts of carbon in the graphite mold makes it easy for $\mathrm{C}$ atoms to enter the bioglass interior.

Five repeated three-point bending tests were carried out for HAP-45S5 bioglass laminar composites and monolayer HAP composites, and the bending strength was $28 \pm 10 \mathrm{MPa}$ and $79.8 \pm 14 \mathrm{MPa}$, respectively. The stress-strain curves are drawn from the three-point bending data of two groups of tests whose bending strength is closest to the average value. Figure 7 shows the engineering stress-strain curves of monolayer HAP composite and HAP-45S5 bioglass laminar composite. At the beginning of the strain, the stress of the monolayer HAP composite shows a significant increase and the fracture occurs when the strain reaches $0.31 \%$ with a corresponding stress of $42.2 \mathrm{MPa}$. During the initial period, the strain of the HAP-45S5 bioglass layered composite reaches $1 \%$ and the stress increases from $2.1 \mathrm{MPa}$ to $3.8 \mathrm{MPa}$. At the strain of $1 \%$, the stress increases significantly with the increase of strain. When the strain reaches $5.9 \%$, the stress achieves the maximum value of 79.8 MPa. The strain and stress of HAP ceramics both are increased by 19 times and 1.89 times after adding $45 \mathrm{~S} 5$ bioglass as the intermediate layer. Therefore, the lamellar structure is very beneficial for the improvement of the toughness of the material. The results indicated that HAP-45S5 bioglass laminar composites have significantly higher strength compared to HAP-bioglass monolayer sintered bodies reported previously [65]. 

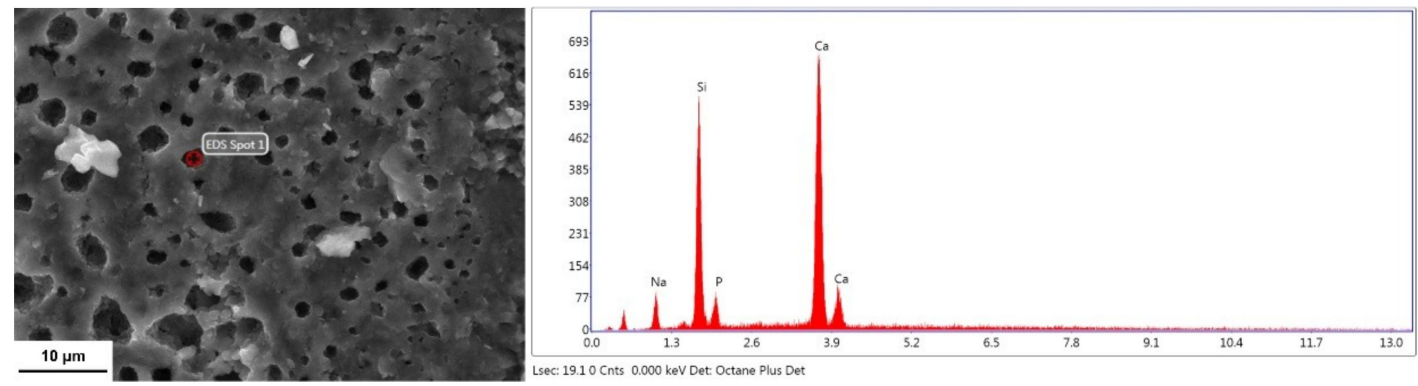

(a)
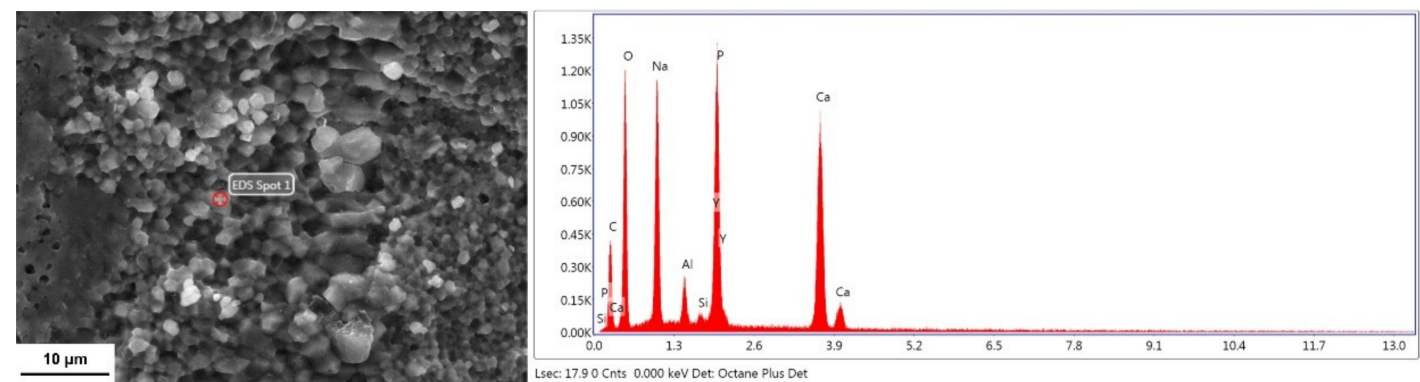

(b)
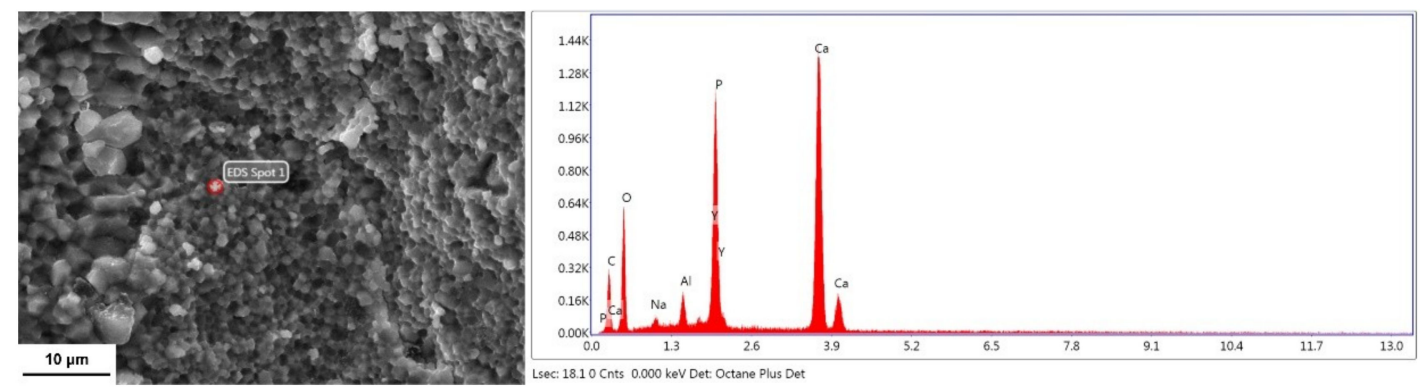

(c)

Figure 6. EDS patterns of the fracture surface of HAP-45S5 bioglass composite: (a) $45 \mathrm{~S} 5$ bioglass layer; (b) HAP coarse grain layer and (c) HAP fine grain layer.

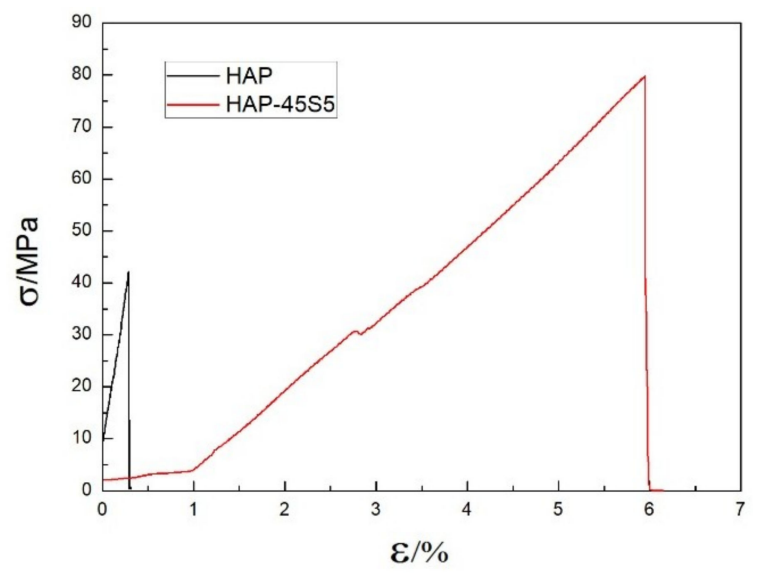

Figure 7. The engineering stress-strain curves of monolayer HAP composite and HAP-45S5 bioglass laminar composite.

Previously discussed by several authors in the literature [27,43], HAP-Bioglass composites do not negatively affect the cells. The same holds both for fibroblasts and for osteocytes [66,67]. Compared to the conventional sintering practice [31-33], the milder processing conditions during the 
SPS process, such as the compaction pressure, sintering time, and temperature, produced HAP-45S5 bioglass laminar composite without excessive reactions between the constituents and prevented the crystallization of the bioglass [35]. Compared with autogenous bone transplantation, synthetic biomaterials are available indefinitely, relatively inexpensive, completely sterile, and require no additional surgery $[43,68]$. Many studies also show that synthetic bone transplantation can effectively respond to soft tissue growth, new bone formation, and biodegradation after transplantation [69]. Results indicated that improvement of the mechanical properties could be obtained with the stratified structure, and suggest that HAP-45S5 bioglass laminated composite might be a good candidate for biomedical applications such as scaffold materials [35,53,70], bone grafts used in dentistry [37,41,43,71], filling bone defects $[33,36,44]$, and facial bone reconstruction $[38,69]$ for bone regeneration/repair.

\section{Conclusions}

Laminated HAP-45S5 bioglass ceramics were successfully prepared by SPS, in which the HAP layers and 45S5 bioglass layers are alternately attacked with smooth and strong interfacial bonding. Remarkable diffusion of $\mathrm{Ca}$ and $\mathrm{Na}$ takes place at the interface between the 45S5 bioglass layer and the HAP coarse grain layer. Meanwhile, a moderate P diffusion also occurs from the HAP layer to the 45S5 bioglass layer. Compared to HAP ceramics, the laminated HAP-45S5 composite showed a significant increase of tensile strength (19 times) and elongation (1.89 times). Therefore, the incorporation of $45 \mathrm{~S} 5$ bioglass to create the laminated composite structure is highly favorable for greatly enhancing the mechanical properties of HAP ceramics.

Author Contributions: Data Curation, Y.M.; Formal Analysis, Y.M. and J.P.; Investigation, Y.M.; Methodology, Y.M.; Supervision, W.Q.; Writing-Original Draft, Y.M.; Writing-Review \& Editing, Y.M. and J.P.

Funding: This research received no external funding.

Conflicts of Interest: The authors declare no conflicts of interest.

\section{References}

1. Xie, Y.; Cheng, L.; Li, L.; Mei, H.; Zhang, L. Strengthening/toughening of laminated SiCw/SiC ceramic composites by heat treatment. Ceram. Int. 2015, 41, 10024-10029. [CrossRef]

2. Xiang, L.; Cheng, L.; Hou, Y.; Wang, F.; Li, L.; Zhang, L. Fabrication and mechanical properties of laminated HfC-SiC/BN ceramics. J. Eur. Ceram. Soc. 2014, 34, 3635-3640. [CrossRef]

3. Shi, G.; Wu, Z.; Wang, Z.; Liang, J. The mechanical properties and microstructure of the bionic alloy-ceramic laminated composite. Mater. Des. 2012, 33, 300-305. [CrossRef]

4. Wang, C.; Huang, Y.; Zan, Q.; Guo, H.; Cai, S. Biomimetic structure design-A possible approach to change the brittleness of ceramics in nature. Mater. Sci. Eng. C 2000, 11, 9-12. [CrossRef]

5. Vecchio, K.S.; Jiang, F. Fracture toughness of Ceramic-Fiber-Reinforced Metallic-Intermetallic-Laminate (CFR-MIL) composites. Mater. Sci. Eng. A 2016, 649, 407-416. [CrossRef]

6. Clegg, W.J.; Kendall, K.; Alford, N.M.; Button, T.W.; Birchall, J.D. A simple way to make tough ceramics. Nature 1990, 347, 455-457. [CrossRef]

7. Xie, Y.; Cheng, L.; Li, L.; Mei, H.; Zhang, L. Fabrication of laminated SiCw/SiC ceramic composites by CVI. J. Eur. Ceram. Soc. 2013, 33, 1701-1706. [CrossRef]

8. Lü, Z.; Jiang, D.; Zhang, J.; Lin, Q.; Huang, Z. ZrB $2-S i C$ laminated ceramic composites. J Eur. Ceram. Soc. 2012, 32, 1435-1439. [CrossRef]

9. Wang, H.; Fan, B.; Feng, L.; Chen, D.; Lu, H.; Xu, H.; Wang, C.; Zhang, R. The fabrication and mechanical properties of $\mathrm{SiC} / \mathrm{ZrB}_{2}$ laminated ceramic composite prepared by spark plasma sintering. Ceram. Int. 2012, 38, 5015-5022. [CrossRef]

10. Yang, G.; Liu, Y.; Qiao, G.; Yang, J.; Wang, H. Preparation and R-curve properties of laminated $\mathrm{Si} / \mathrm{SiC}$ ceramics from paper. Mater. Sci. Eng. A 2008, 492, 327-332. [CrossRef]

11. Hadad, M.; Blugan, G.; Kübler, J.; Rosset, E.; Rohr, L.; Michler, J. Tribological behaviour of $\mathrm{Si}_{3} \mathrm{~N}_{4}$ and $\mathrm{Si}_{3} \mathrm{~N}_{4}-\%$ TiN based composites and multi-layer laminates. Wear 2006, 260, 634-641. [CrossRef] 
12. Blugan, G.; Dobedoe, R.; Lugovy, M.; Koebel, S.; Kuebler, J. $\mathrm{Si}_{3} \mathrm{~N}_{4}$-TiN based micro-laminates with rising R-curve behaviour. Compos. Part B Eng. 2006, 37, 459-465. [CrossRef]

13. Mukherjee, S.; Kundu, B.; Chanda, A.; Sen, S. Effect of functionalisation of CNT in the preparation of HAp-CNT biocomposites. Ceram. Int. 2015, 41, 3766-3774. [CrossRef]

14. White, A.A.; Best, S.M.; Kinloch, I.A. Hydroxyapatite? Carbon Nanotube Composites for Biomedical Applications: A Review. Int. J. Appl. Ceram. Technol. 2007, 4, 1-13. [CrossRef]

15. Khanal, S.P.; Mahfuz, H.; Rondinone, A.J.; Leventouri, T. Improvement of the fracture toughness of hydroxyapatite (HAp) by incorporation of carboxyl functionalized single walled carbon nanotubes (CfSWCNTs) and nylon. Mater. Sci. Eng. C 2016, 60, 204-210. [CrossRef] [PubMed]

16. Htun, Z.L.; Ahmad, N.; Thant, A.A.; Noor, A.M. Characterization of $\mathrm{CaO}-\mathrm{ZrO}_{2}$ Reinforced Hap Biocomposite for Strength and Toughness Improvement. Procedia Chem. 2016, 19, 510-516. [CrossRef]

17. Ankur, G.; Garima, T.; Debrupa, L.; Kantesh, B. Compression Molded Ultra High Molecular Weight Polyethylene-Hydroxyapatite-Aluminum Oxide-Carbon Nanotube Hybrid Composites for Hard Tissue Replacement. J. Mater. Sci. Technol. 2013, 29, 514-522.

18. Lee, B.; Lee, C.; Youn, M.; Song, H. Relationship between microstructure and mechanical properties of fibrous HAp-(t- $\left.\mathrm{ZrO}_{2}\right) / \mathrm{Al}_{2} \mathrm{O}_{3}-\left(\mathrm{m}-\mathrm{ZrO}_{2}\right)$ composites. Mater. Sci. Eng. A 2007, 458, 11-16. [CrossRef]

19. Deng, M.; Wen, H.L.; Dong, X.L.; Li, F.; Xu, X.; Li, H.; Li, J.Y.; Zhou, X.D. Effects of $45 S 5$ bioglass on surface properties of dental enamel subjected to 35\% hydrogen peroxide. Int. J. Oral Sci. 2013, 5, 103-110. [CrossRef]

20. Kashyap, S.; Griep, K.; Nychka, J.A. Crystallization kinetics, mineralization and crack propagation in partially crystallized bioactive glass 45S5. Mater. Sci. Eng. C 2011, 31, 762-769. [CrossRef]

21. Cacciotti, I.; Lombardi, M.; Bianco, A.; Ravaglioli, A.; Montanaro, L. Sol-gel derived $45 \mathrm{~S} 5$ bioglass: Synthesis, microstructural evolution and thermal behaviour. J. Mater. Sci. Mater. Med. 2012, 23, 1849-1866. [CrossRef] [PubMed]

22. Touri, R.; Moztarzadeh, F.; Sadeghian, Z.; Bizari, D.; Tahriri, M.; Mozafari, M. The use of carbon nanotubes to reinforce 45S5 bioglass-based scaffolds for tissue engineering applications. Biomed. Res. Int. 2013, 2013, 465086. [CrossRef] [PubMed]

23. Hench, L.L. The story of Bioglass (R). J. Mater. Sci.-Mater. Med. 2006, 17, 967-978. [CrossRef] [PubMed]

24. Porwal, H.; Grasso, S.; Cordero-Arias, L.; Li, C.; Boccaccini, A.R.; Reece, M.J. Processing and bioactivity of 45S5 Bioglass((R))-graphene nanoplatelets composites. J. Mater. Sci. Mater. Med. 2014, 25, 1403-1413. [CrossRef] [PubMed]

25. Plewinski, M.; Schickle, K.; Lindner, M.; Kirsten, A.; Weber, M.; Fischer, H. The effect of crystallization of bioactive bioglass $45 S 5$ on apatite formation and degradation. Dent. Mater. 2013, 29, 1256-1264. [CrossRef] [PubMed]

26. Jia, Z.; Zhang, J.; Jia, C.; Nie, J.; Chu, K. Preparation and characterization of mechanical properties of carbon nanotube/45S5Bioglass composites for biologic applications. Mater. Sci. Eng. A 2011, 528, 1553-1557. [CrossRef]

27. Mondal, S.; Hoang, G.; Manivasagan, P.; Moorthy, M.S.; Nguyen, T.P.; Vy Phan, T.T.; Kim, H.H.; Kim, M.H.; Nam, S.Y.; Oh, J. Nano-hydroxyapatite bioactive glass composite scaffold with enhanced mechanical and biological performance for tissue engineering application. Ceram. Int. 2018, 44, 15735-15746. [CrossRef]

28. Sebdani, M.M.; Fathi, M.H. Novel hydroxyapatite-forsterite-bioglass nanocomposite coatings with improved mechanical properties. J. Alloy Compd. 2011, 509, 2273-2276. [CrossRef]

29. Melinte, G.; Baia, L.; Simon, V.; Simon, S. Hydrogen peroxide versus water synthesis of bioglass-nanocrystalline hydroxyapatite composites. J. Mater. Sci. 2011, 46, 7393-7400. [CrossRef]

30. Ravarian, R.; Moztarzadeh, F.; Hashjin, M.S.; Rabiee, S.M.; Khoshakhlagh, P.; Tahriri, M. Synthesis, characterization and bioactivity investigation of bioglass/hydroxyapatite composite. Ceram. Int. 2010, 36, 291-297. [CrossRef]

31. Meng, Y.H.; Tang, C.Y.; Tsui, C.P. Fabrication and Characterization of Bioglass-Modified $\mathrm{HA}_{-} \mathrm{ZrO}_{2}$ Biocomposites. Compos. Interface 2012, 17, 551-558. [CrossRef]

32. Demirkiran, H.; Hu, Y.; Zuin, L.; Appathurai, N.; Aswath, P.B. XANES analysis of calcium and sodium phosphates and silicates and hydroxyapatite-Bioglass ${ }^{\circledR} 45 \mathrm{~S} 5$ co-sintered bioceramics. Mater. Sci. Eng. C 2011, 31, 134-143. [CrossRef] 
33. Bellucci, D.; Sola, A.; Anesi, A.; Salvatori, R.; Chiarini, L.; Cannillo, V. Bioactive glass/hydroxyapatite composites: Mechanical properties and biological evaluation. Mater. Sci. Eng. C 2015, 51, 196-205. [CrossRef] [PubMed]

34. Thamma, U.; Kowal, T.; Falk, M.; Jain, H. Influence of nanoporosity on the nature of hydroxyapatite formed on bioactive calcium silicate model glass. J. Biomed. Mater. Res. B Appl. Biomater. 2018. [CrossRef] [PubMed]

35. Rizwan, M.; Hamdi, M.; Basirun, W.J.; Kondoh, K.; Umeda, J. Low pressure spark plasma sintered hydroxyapatite and Bioglass ${ }^{\circledR}$ composite scaffolds for bone tissue repair. Ceram. Int. 2018, 44, 23052-23062. [CrossRef]

36. Bellucci, D.; Desogus, L.; Montinaro, S.; Orrù, R.; Cao, G.; Cannillo, V. Innovative hydroxyapatite/bioactive glass composites processed by spark plasma sintering for bone tissue repair. J. Eur. Ceram. Soc. 2017, 37, 1723-1733. [CrossRef]

37. Kim, B.; Prajatelistia, E.; Han, Y.; Son, H.; Sakka, Y.; Kim, S. Transparent hydroxyapatite ceramics consolidated by spark plasma sintering. Scr. Mater. 2013, 69, 366-369. [CrossRef]

38. Akin, I.; Goller, G. Processing Technologies for Bioceramic Based Composites. Handb. Bioceram. Biocompos. 2015, 639-666. [CrossRef]

39. Bertolla, L.; Dlouhý, I.; Tatarko, P.; Viani, A.; Mahajan, A.; Chlup, Z.; Reece, M.J.; Boccaccini, A.R. Pressureless spark plasma-sintered Bioglass ${ }^{\circledR} 45 \mathrm{~S} 5$ with enhanced mechanical properties and stress-induced new phase formation. J. Eur. Ceram. Soc. 2017, 37, 2727-2736. [CrossRef]

40. Grasso, S.; Chinnam, R.K.; Porwal, H.; Boccaccini, A.R.; Reece, M.J. Low temperature spark plasma sintering of 45S5 Bioglass ${ }^{\circledR}$. J. Non-Cryst. Solids 2013, 362, 25-29. [CrossRef]

41. Gergely, G.; Sahin, F.C.; Göller, G.; Yücel, O.; Balázsi, C. Microstructural and mechanical investigation of hydroxyapatite-zirconia nanocomposites prepared by spark plasma sintering. J. Eur. Ceram. Soc. 2013, 33, 2313-2319. [CrossRef]

42. Dubey, A.K.; Sitesh, G.; Nath, S.; Basu, B. Spark plasma sintering to restrict sintering reactions and enhance properties of hydroxyapatite-mullite biocomposites. Ceram. Int. 2011, 37, 2755-2761. [CrossRef]

43. Figueiredo, A.; Coimbra, P.; Cabrita, A.; Guerra, F.; Figueiredo, M. Comparison of a xenogeneic and an alloplastic material used in dental implants in terms of physico-chemical characteristics and in vivo inflammatory response. Mater. Sci. Eng. C 2013, 33, 3506-3513. [CrossRef] [PubMed]

44. Clauss, M.; Trampuz, A.; Borens, O.; Bohner, M.; Ilchmann, T. Biofilm formation on bone grafts and bone graft substitutes: Comparison of different materials by a standard in vitro test and microcalorimetry. Acta Biomater. 2010, 6, 3791-3797. [CrossRef] [PubMed]

45. Bellucci, D.; Sola, A.; Cannillo, V. Hydroxyapatite and tricalcium phosphate composites with bioactive glass as second phase: State of the art and current applications. J. Biomed. Mater. Res. A 2016, 104, 1030-1056. [CrossRef] [PubMed]

46. Wheeler, D.L.; Montfort, M.J.; McLoughlin, S.W. Differential healing response of bone adjacent to porous implants coated with hydroxyapatite and $45 S 5$ bioactive glass. J. Biomed. Mater. Res. 2001, 55, 603-612. [CrossRef]

47. Tkachenko, S.; Cizek, J.; Mušálek, R.; Dvořák, K.; Spotz, Z.; Montufar, E.B.; Chráska, T.; Křupka, I.; Čelko, L. Metal matrix to ceramic matrix transition via feedstock processing of SPS titanium composites alloyed with high silicone content. J. Alloy Compd. 2018, 764, 776-788. [CrossRef]

48. Montufar, E.B.; Casas-Luna, M.; Horynová, M.; Tkachenko, S.; Fohlerová, Z.; Diaz-de-la-Torre, S.; Dvořák, K.; Čelko, L.; Kaiser, J. High strength, biodegradable and cytocompatible alpha tricalcium phosphate-iron composites for temporal reduction of bone fractures. Acta Biomater. 2018, 70, 293-303. [CrossRef]

49. Yang, H.; Qu, X.; Lin, W.; Wang, C.; Zhu, D.; Dai, K.; Zheng, Y. In vitro and in vivo studies on zinc-hydroxyapatite composites as novel biodegradable metal matrix composite for orthopedic applications. Acta Biomater. 2018, 71, 200-214. [CrossRef]

50. Tkachenko, S.; Horynová, M.; Casas-Luna, M.; Diaz-de-la-Torre, S.; Dvořák, K.; Celko, L.; Kaiser, J.; Montufar, E.B. Strength and fracture mechanism of iron reinforced tricalcium phosphate cermet fabricated by spark plasma sintering. J. Mech. Behav. Biomed. 2018, 81, 16-25. [CrossRef]

51. Jia, L.; Li, S.; Imai, H.; Chen, B.; Kondoh, K. Size effect of B4C powders on metallurgical reaction and resulting tensile properties of Ti matrix composites by in-situ reaction from Ti-B4C system under a relatively low temperature. Mater. Sci. Eng. A 2014, 614, 129-135. [CrossRef] 
52. Meng, Y.; Qiang, W.; Pang, J. Preparation and characterization of mechanical properties of carbon nanotube reinforced hydroxyapatite composites consolidated by spark plasma sintering. IOP Conf. Ser. Mater. Sci. Eng. 2017, 231, 12164. [CrossRef]

53. Chen, Q.Z.; Xu, J.L.; Yu, L.G.; Fang, X.Y.; Khor, K.A. Spark plasma sintering of sol-gel derived $45 S 5$ Bioglass ${ }^{\circledR}$-ceramics: Mechanical properties and biocompatibility evaluation. Mater. Sci. Eng. C 2012, 32, 494-502. [CrossRef]

54. Kim, Y.G.; Seo, D.S.; Lee, J.K. Dissolution of synthetic and bovine bone-derived hydroxyapatites fabricated by hot-pressing. Appl. Surf. Sci. 2008, 255, 589-592. [CrossRef]

55. Miranda, G.; Araújo, A.; Bartolomeu, F.; Buciumeanu, M.; Carvalho, O.; Souza, J.C.M.; Silva, F.S.; Henriques, B. Design of Ti6Al4V-HA composites produced by hot pressing for biomedical applications. Mater. Des. 2016, 108, 488-493. [CrossRef]

56. Rapacz-Kmita, A.; Paluszkiewicz, C.; Ślósarczyk, A.; Paszkiewicz, Z. FTIR and XRD investigations on the thermal stability of hydroxyapatite during hot pressing and pressureless sintering processes. J. Mol. Struct. 2005, 744-747, 653-656. [CrossRef]

57. Xihua, Z.; Changxia, L.; Musen, L.; Yunqiang, B.; Junlong, S. Fabrication of hydroxyapatite/diopside/alumina composites by hot-press sintering process. Ceram. Int. 2009, 35, 1969-1973. [CrossRef]

58. Brzezińska-Miecznik, J.; Macherzyńska, B.; Lach, R.; Nowak, B. The effect of calcination and zirconia addition on HAp hot pressed materials. Ceram. Int. 2014, 40, 15815-15819. [CrossRef]

59. Tancred, D.C.; McCormack, B.A.O.; Carr, A.J. A quantitative study of the sintering and mechanical properties of hydroxyapatite/phosphate glass composites. Biomaterials 1998, 19, 1735-1743. [CrossRef]

60. Filho, H.N.; Pinto, T.F.; de Freitas, C.P.; Ribeiro-Junior, P.D.; Dos Santos, P.L.; Matsumoto, M.A. Autogenous Bone Grafts Contamination After Exposure to the Oral Cavity. J. Craniofac. Surg. 2014, 25, 412-414. [CrossRef]

61. Vignoles, M.; Bonel, G.; Young, R.A. Occurrence of nitrogenous species in precipitated B-type carbonated hydroxyapatites. Calcif. Tissue Int. 1987, 40, 64-70. [CrossRef] [PubMed]

62. Feki, H.E.; Savariault, J.M.; Salah, A.B. Structure refinements by the Rietveld method of partially substituted hydroxyapatite: $\mathrm{Ca}_{9} \mathrm{Na}_{0.5}\left(\mathrm{PO}_{4}\right)_{4.5}\left(\mathrm{CO}_{3}\right)_{1.5}(\mathrm{OH})_{2}$. J. Alloy Compd. 1999, 287, 114-120. [CrossRef]

63. Desogus, L.; Cuccu, A.; Montinaro, S.; Orrù, R.; Cao, G.; Bellucci, D.; Sola, A.; Cannillo, V. Classical Bioglass ${ }^{\circledR}$ and innovative $\mathrm{CaO}$-rich bioglass powders processed by Spark Plasma Sintering: A comparative study. J. Eur. Ceram. Soc. 2015, 35, 4277-4285. [CrossRef]

64. Cerruti, M.; Morterra, C. Carbonate Formation on Bioactive Glasses. Langmuir 2004, 20, 6382-6388. [CrossRef] [PubMed]

65. Oktar, F.N.; Göller, G. Sintering effects on mechanical properties of glass-reinforced hydroxyapatite composites. Ceram. Int. 2002, 28, 617-621. [CrossRef]

66. Hoppe, A.; Güldal, N.S.; Boccaccini, A.R. A review of the biological response to ionic dissolution products from bioactive glasses and glass-ceramics. Biomaterials 2011, 32, 2757-2774. [CrossRef] [PubMed]

67. Xynos, I.D.; Hukkanen, M.V.J.; Batten, J.J.; Buttery, L.D.; Hench, L.L.; Polak, J.M. Bioglass ${ }^{\circledR} 45 S 5$ Stimulates Osteoblast Turnover and Enhances Bone Formation In Vitro: Implications and Applications for Bone Tissue Engineering. Calcif. Tissue Int. 2000, 67, 321-329. [CrossRef]

68. Sakkas, A.; Wilde, F.; Heufelder, M.; Winter, K.; Schramm, A. Autogenous bone grafts in oral implantology-Is it still a "gold standard"? A consecutive review of 279 patients with 456 clinical procedures. Int. J. Implant Dent. 2017, 3, 23. [CrossRef]

69. Cicciù, M.; Cervino, G.; Herford, A.; Famà, F.; Bramanti, E.; Fiorillo, L.; Lauritano, F.; Sambataro, S.; Troiano, G.; Laino, L. Facial Bone Reconstruction Using both Marine or Non-Marine Bone Substitutes: Evaluation of Current Outcomes in a Systematic Literature Review. Mar. Drugs 2018, 16, 27. [CrossRef]

70. Bellucci, D.; Sola, A.; Cannillo, V. Bioactive glass-based composites for the production of dense sintered bodies and porous scaffolds. Mater. Sci. Eng. C 2013, 33, 2138-2151. [CrossRef]

71. Shue, L.; Yufeng, Z.; Mony, U. Biomaterials for periodontal regeneration. Biomatter 2012, 4, $271-277$. [CrossRef] [PubMed]

(C) 2019 by the authors. Licensee MDPI, Basel, Switzerland. This article is an open access article distributed under the terms and conditions of the Creative Commons Attribution (CC BY) license (http://creativecommons.org/licenses/by/4.0/). 